\title{
Assessment of Rheumatoid Arthritis Quality Process Measures and Associated Costs
}

\author{
Brenna L. Brady, PhD, Joseph Tkacz, MS, Roxanne Meyer, PharmD, \\ Susan C. Bolge, $\mathrm{PhD}^{2}$, and Charles Ruetsch, $\mathrm{PhD}^{1}$
}

\begin{abstract}
The objective was to examine the relationship between health care costs and quality in rheumatoid arthritis (RA). Administrative claims were used to calculate 8 process measures for the treatment of RA. Associated health care costs were calculated for members who achieved or did not achieve each of the measures. Medical, pharmacy, and laboratory claims for RA patients (International Classification of Diseases, Ninth Revision, Clinical Modification 714.x) were extracted from the Optum Clinformatics Datamart database for 2011. Individuals were predominately female and in their mid-fifties. Measure achievement ranged from $55.9 \%$ to $80.8 \%$. The mean cost of care for members meeting the measure was $\$ 18,644$; members who did not meet the measures had a mean cost of $\$ 14,973$. Primary cost drivers were pharmacy and office expenses, accounting for $42.4 \%$ and $26.3 \%$ of total costs, respectively. Regression analyses revealed statistically significant associations between biologic usage, which was more prevalent in groups attaining measures, and total expenditure across all measures $(P \mathrm{~s}<0.001)$. Pharmacy costs were similar between both groups. Individuals meeting the measures had a higher proportion of costs accounted for by office visits; those not meeting the measures had a higher proportion of costs from inpatient and outpatient visits. These findings suggest that increased quality may lead to lower inpatient and outpatient hospital costs. Yet, the overall cost of RA care is likely to remain high because of intensive pharmacotherapy regimens.
\end{abstract}

\section{Introduction}

$\mathbf{C}$ HRONIC DISEASES SUCH AS rheumatoid arthritis (RA) represent a large burden on health care systems because of increased use of services over time. ${ }^{1}$ Patients with poorly maintained chronic diseases can further increase these cost burdens because of augmented use of health care services. Conversely, increased patient involvement, initiation of proper treatment pathways, and timely interventions can aid patients in controlling chronic disease progression, thereby reducing the overall burden of disease on both the patient and health care system..$^{2-5}$ Due to the positive association between disease severity and higher health care costs, increased quality in health care could not only result in healthier patients, but reduce overall costs by slowing or mitigating disease progression. Therefore, quality of RA care, especially early in treatment when the disease course may be altered, is relevant to both patients and payers.
RA is a chronic, inflammatory autoimmune disease primarily affecting the synovial joints. ${ }^{6}$ If properly controlled, RA can be manageable and exhibit periods of remission, ${ }^{7}$ but uncontrolled RA can lead to involvement of other organ systems causing increased comorbidities and mortalities. From the patient perspective, uncontrolled RA results in increased pain, fatigue, and reduced quality of life, affecting activity and the ability to work. ${ }^{8}$ RA affects $0.5 \%$ to $1 \%$ of the population with estimated annual medical costs ranging from $\$ 2000$ to $\$ 10,000$ per patient ${ }^{8}$; indirect costs are estimated to be at least equal to, if not more than, direct costs. ${ }^{8-10}$

The range of medical costs associated with RA is in part related to various treatment options. Treatment for RA focuses on control and management of inflammation. Patients with new RA diagnoses or less severe disease usually are prescribed less expensive nonbiologic disease modifying antirheumatic drugs (DMARDs) to control inflammation, while patients who do not respond to DMARD treatment or

\footnotetext{
${ }^{1}$ Health Analytics, LLC, Columbia, Maryland.

${ }^{2}$ Janssen Scientific Affairs, Horsham, Pennsylvania.
}

(C) Brady et al. 2016; Published by Mary Ann Liebert, Inc. This Open Access article is distributed under the terms of the Creative Commons Attribution Noncommercial License (http://creativecommons.org/licenses/by-nc/4.0/) which permits any noncommercial use, distribution, and reproduction in any medium, provided the original author(s) and the source are credited. 
exhibit more advanced disease are more likely to be treated with biologic therapies. ${ }^{11}$ Though treatment of RA with the use of biologic therapies is reported to be 3 times more expensive than use of nonbiologic DMARDs, ${ }^{12}$ the initial cost of biologic therapy may be offset through reduced disease progression, service utilization, and health care expenditures over the course of disease. ${ }^{13}$ Although the cost savings associated with biologic therapies remains indefinite, ${ }^{13}$ it is clear that slowing the progression of RA not only yields healthier patients but also results in lower costs. ${ }^{2,12,14}$

There is a movement to increase the quality of health care in the United States in hope of yielding improved patient outcomes, and the medical community has responded through the institution and improvement of quality measures for RA. Further, increased emphasis is being placed on early aggressive treatment, ${ }^{9,15,16}$ involvement of patient preference in treatment choices, ${ }^{3,4,17}$ and the consideration of costs in treatment decisions. ${ }^{18}$ To ensure quality health care for RA patients, various groups, such as the American College of Rheumatology, the National Committee for Quality Assurance, the Physician Quality Reporting System, and the National Quality Forum (NQF), have released sets of measures intended for physician and health plan use to standardize and improve the quality of RA care. The study team has previously defined 8 process measures endorsed by the NQF from December 4, 2009, to July 21, 2014, for use with administrative claims data. ${ }^{19}$ Currently, the association between health care costs and quality of care remains unclear, with studies reporting both positive and negative correlations between cost and quality. ${ }^{20}$ The purpose of the present study is to examine the relationship between RA quality process measures and health care expenditures among a commercially insured sample of RA patients using administrative claims data.

\section{Methods}

\section{Study sample}

Study data derived from the Optum Clinformatics DataMart database (Optuminsight Life Sciences, Inc., Eden Prairie, MN). Medical, pharmacy, and laboratory claims for members with a diagnosis of RA (International Classification of Diseases, Ninth Revision, Clinical Modification [ICD-9CM] 714.x) during calendar year 2011 were extracted.

\section{Measures}

Process measures. Table 1 contains the official descriptions of the $8 \mathrm{RA}$ process measures examined in this study. $^{21}$ The measures were endorsed by the NQF from December 4, 2009, through July 21, 2014. At the July 2104 evaluation, 7 of the 8 measures (all except measure 0054) had their NQF endorsement removed. The measures generally focus on patient response and tolerance to therapy, and were designed to be calculated over an individual calendar year. The following 2 components were defined for each measure to allow for calculation in claims:

1. Denominator statement. The number of patients older than age 18 who meet criteria for an RA diagnosis during either the measurement year or previous year. Denominator statements also specify additional inclusion criterion based on the particular type of patient the measure was designed to assess (eg, new DMARD initiator, existing methotrexate user).

2. Numerator statement. A subset of patients in the denominator who receive some form of treatment or lab test that is indicative of quality patient care.

For all denominator statements, patients were required to be continuously eligible for the entire year, and must have met the following criteria for a diagnosis of RA during the year: 2 claims on 2 separate dates with (1) a primary diagnosis of RA (ICD-9-CM 714.x), and (2) a place of service code for either "office" or "outpatient hospital."

For measures requiring the detection of ambulatory or oral DMARD utilization, the "brand name" field in the pharmacy table was used to identify relevant medications. For measures 0589 and 0590, which did not restrict DMARD usage to ambulatory fills, J-codes appearing in the "procedure code" field on the medical record were used in addition to the pharmacy record. For measures requiring the detection of lab tests, appropriate Current Procedural Terminology codes in the medical record were used. The laboratory results table was not used in any of the calculations, as measures were designed to consider billing claims only. All measures were calculated during calendar year 2011 .

Demographic characteristics. Patient demographics were summarized from the membership table. Measures included age, sex, geographic region of residence, insurance line of business, and type of benefit plan. The Charlson comorbidity index, an overall measure of health, ${ }^{22}$ was calculated over the year, as were the rates for a variety of other comorbidities of interest. Because each process measure contains specific inclusion and exclusion criteria resulting in the creation of a unique sample for each measure, analyses of demographics included all members meeting both the overall age and RA diagnosis criteria.

Health care service utilization and costs. Primary dependent variables included the following health service outcomes measured during calendar year 2011:

- total prescription fills (adjusted for 30-day supplies) and costs,

- office visits and costs,

- inpatient hospital admissions, days, and costs,

- outpatient visits and costs,

- emergency room (ER) visits and costs,

- total medical costs, and

- total health care costs (medical + pharmacy costs).

A maximum of 1 inpatient admission, ER visit, and outpatient hospital visit were assumed per day. Multiple office visits were allowed in a single day, though they must have been associated with unique provider IDs. Biologic DMARD infusions appear as medical costs.

\section{Data analyses}

For each measure, patients were placed into groups based on whether the claims record had evidence of the patient meeting or not meeting the measure numerator. Across measure groups, descriptive statistics were reported for all demographic, health care service utilization, and health care expenditure measures. Means and standard deviations were 


\begin{tabular}{|c|c|c|c|}
\hline & Measure description & Numerator statement & Denominator statement \\
\hline $\begin{array}{l}0054 \text { Disease- } \\
\text { modifying } \\
\text { antirheumatic } \\
\text { drug (DMARD) } \\
\text { therapy in } \\
\text { rheumatoid } \\
\text { arthritis }\end{array}$ & $\begin{array}{l}\text { Percentage of patients } \\
18 \text { years and older, } \\
\text { diagnosed with } \\
\text { RA who have had } \\
\text { at least } 1 \text { ambulatory } \\
\text { prescription dispensed } \\
\text { for a DMARD. }\end{array}$ & $\begin{array}{l}\text { Patients who had at least } 1 \\
\text { ambulatory prescription } \\
\text { dispensed for a DMARD } \\
\text { during the measurement } \\
\text { year. }\end{array}$ & $\begin{array}{l}\text { Patients } \geq 18 \text { years old as } \\
\text { of December } 31 \text { of the } \\
\text { measurement year, with } \\
\text { a diagnosis of RA. Two } \\
\text { face-to-face physician } \\
\text { encounters with an RA } \\
\text { diagnosis with different } \\
\text { dates of service in an } \\
\text { ambulatory or nonacute } \\
\text { inpatient setting between } \\
\text { January } 1 \text { and November } \\
30 \text { of the measurement } \\
\text { year are required to } \\
\text { confirm an RA diagnosis. }\end{array}$ \\
\hline $\begin{array}{l}0589 \text { RA new } \\
\text { DMARD baseline } \\
\text { serum creatinine }\end{array}$ & $\begin{array}{l}\text { This measure identifies } \\
\text { adult patients with a } \\
\text { diagnosis of RA who } \\
\text { received appropriate } \\
\text { baseline serum } \\
\text { creatinine testing within } \\
90 \text { days before to } 14 \text { days } \\
\text { after the new start of } \\
\text { methotrexate, leflunomide, } \\
\text { azathioprine, D- } \\
\text { Penicillamine, intramuscular } \\
\text { gold, cyclosporine, or } \\
\text { cyclophosphamide during } \\
\text { the measurement year. }\end{array}$ & $\begin{array}{l}\text { Patients in the denominator } \\
\text { who received serum } \\
\text { creatinine testing within } \\
90 \text { days before to } 14 \text { days } \\
\text { after the new start of } \\
\text { methotrexate, leflunomide, } \\
\text { azathioprine, D-Penicillamine, } \\
\text { intramuscular gold, } \\
\text { cyclosporine, or } \\
\text { cyclophosphamide during } \\
\text { the measurement year. }\end{array}$ & $\begin{array}{l}\text { Patients } \geq 18 \text { years old with } \\
\text { a history of RA and a new } \\
\text { start of methotrexate, } \\
\text { leflunomide, azathioprine, } \\
\text { D-Penicillamine, } \\
\text { intramuscular gold, } \\
\text { cyclosporine, or } \\
\text { cyclophosphamide anytime } \\
\text { from the beginning of the } \\
\text { measurement year to } \\
14 \text { days prior to the end } \\
\text { of the measurement year. }\end{array}$ \\
\hline $\begin{array}{l}0590 \text { RA new } \\
\text { DMARD baseline } \\
\text { liver function } \\
\text { test (LFT) }\end{array}$ & $\begin{array}{l}\text { This measure identifies adult } \\
\text { patients with a diagnosis of } \\
\text { RA who received } \\
\text { appropriate baseline liver } \\
\text { function testing (AST or } \\
\text { ALT) within } 90 \text { days before } \\
\text { to } 14 \text { days after the new } \\
\text { start of sulfasalazine, } \\
\text { methotrexate, leflunomide, } \\
\text { azathioprine, cyclosporine } \\
\text { or cyclophosphamide during }\end{array}$ & $\begin{array}{l}\text { Patients in the denominator } \\
\text { who received liver function } \\
\text { testing within } 90 \text { days before } \\
\text { to } 14 \text { days after the new } \\
\text { start of sulfasalazine, } \\
\text { methotrexate, leflunomide, } \\
\text { azathioprine, cyclosporine } \\
\text { or cyclophosphamide during } \\
\text { the measurement year. }\end{array}$ & $\begin{array}{l}\text { Patients } \geq 18 \text { years old with } \\
\text { a history of RA and a new } \\
\text { start of sulfasalazine, } \\
\text { methotrexate, leflunomide, } \\
\text { azathioprine, cyclosporine } \\
\text { or cyclophosphamide } \\
\text { anytime from the beginning } \\
\text { of the measurement year } \\
\text { to } 14 \text { days prior to the end } \\
\text { of the measurement year. }\end{array}$ \\
\hline
\end{tabular}

0592 RA annual erythrocyte sedimentation rate (ESR) or C-reactive protein (CRP)

0601 New RA baseline ESR or CRP within 3 months

0597 Methotrexate: LFT within 12 weeks or cyclophosphamide during the measurement year.

This measure identifies adult patients with a history of RA who have received ESR or CRP lab tests during the measurement year.

This measure identifies adult patients newly diagnosed with RA during the first 8 months of the measurement year who received ESR or CRP lab tests either 4 months (3 months +1-month grace period) before or after the initial diagnosis.

This measure identifies adult patients with RA who were prescribed at least a 6-month supply of methotrexate during the measurement year and received a LFT in the 120 days $(3$ months +1 -month grace period) following the earliest observed methotrexate prescription claim.
Patients in the denominator who had an ESR or CRP lab test during the measurement year.

Patients in the denominator who had an ESR or CRP lab test either 4 months before or after the initial RA diagnosis date.

Patients in the denominator who received a LFT within 120 days following the earliest observed methotrexate prescription claim.
Patients $\geq 18$ years old with a history of RA, diagnosed prior to the measurement year.

Patients $\geq 18$ years old newly diagnosed with RA during the first 8 months of the measurement year.

Patients $\geq 18$ years old with RA who have received at least a 6-month supply of oral methotrexate during the measurement year. 
TABle 1. (CONTINUED)

\begin{tabular}{|c|c|c|c|}
\hline & Measure description & Numerator statement & Denominator statement \\
\hline $\begin{array}{l}0598 \text { Methotrexate: } \\
\text { Complete blood } \\
\text { count (CBC) } \\
\text { within } 12 \text { weeks }\end{array}$ & $\begin{array}{l}\text { This measure identifies adult } \\
\text { patients with RA who were } \\
\text { prescribed at least a 6-month } \\
\text { supply of methotrexate during } \\
\text { the measurement year and } \\
\text { received a CBC test within } \\
120 \text { days ( } 3 \text { months }+1 \text {-month } \\
\text { grace period) following the } \\
\text { earliest observed methotrexate } \\
\text { prescription claim. }\end{array}$ & $\begin{array}{l}\text { Patients in the denominator } \\
\text { who received a CBC test } \\
\text { within } 120 \text { days following } \\
\text { the earliest observed } \\
\text { methotrexate } \\
\text { prescription claim. }\end{array}$ & $\begin{array}{l}\text { Patients } \geq 18 \text { years old } \\
\text { with RA who have } \\
\text { received at least a } \\
\text { 6-month supply of oral } \\
\text { methotrexate during the } \\
\text { measurement year. }\end{array}$ \\
\hline $\begin{array}{l}0599 \text { Methotrexate: } \\
\text { Creatinine within } \\
12 \text { weeks }\end{array}$ & $\begin{array}{l}\text { This measure identifies adult } \\
\text { patients with RA who were } \\
\text { prescribed at least a 6-month } \\
\text { supply of methotrexate during } \\
\text { the measurement year and } \\
\text { received a serum creatinine } \\
\text { test in the } 120 \text { days } \\
\text { ( } 3 \text { months }+1 \text {-month grace } \\
\text { period) after the earliest } \\
\text { observed methotrexate } \\
\text { prescription claim. }\end{array}$ & $\begin{array}{l}\text { Patients in the denominator } \\
\text { who received a serum } \\
\text { creatinine or BUN test in } \\
\text { the } 120 \text { days following the } \\
\text { earliest observed } \\
\text { methotrexate prescription } \\
\text { claim. }\end{array}$ & $\begin{array}{l}\text { Patients } \geq 18 \text { years old with } \\
\text { RA who have received } \\
\text { at least a } 6 \text {-month supply } \\
\text { of oral methotrexate } \\
\text { during the measurement } \\
\text { year. }\end{array}$ \\
\hline
\end{tabular}

$\mathrm{ALT}=$ alanine aminotransferase $; \mathrm{AST}=$ aspartate aminotransferase.

reported for scale variables and frequencies and proportions for categorical variables. Chi-square tests of equality of proportions were used to assess statistical significance of categorical variables, and Student $t$ tests were used for the age and Charlson comorbidity index variables. The Kruskal-Wallis test was used to measure group differences on post-period service utilization and cost measures, as distributions were skewed. Total health care costs were entered into gamma models with a log link controlling for biologic use. Marginal effects and standard errors were reported. Data management and analyses were conducted using IBM SPSS Statistics for Windows, version 20 (IBM, Armonk, NY). Overall costs and service utilization were summed across all 8 measures, and data obtained from total summation are presented either as a percentage of total health care costs or average service utilization across groups.

\section{Results}

Overall sample characteristics may be viewed in Table 2 . Members were predominately female, living mainly in the mid-American and the Southeastern regions of the United States, with a mean age of 52.8. ${ }^{19}$ Demographic analyses by measure qualification groups revealed that members in the non-qualifying groups were generally older and had reduced overall health, indicated by a higher Charlson comorbidity index score. Additionally, for all measures with the exception of 0601, which only included new RA members, individuals in the qualifying groups were significantly more likely to be treated with biologic therapy than those in the non-qualifying groups $(P \mathrm{~s}<0.05)$.

Tables 3 and 4 present cost and service utilization based on specific measure qualification, while Table 5 presents cost and service utilization rates across all measures. Pharmacy costs ranged from $\$ 2542$ to $\$ 8765$ in per member annual costs, and accounted for $42.4 \%$ of overall costs.
Table 2. Sample Demographics By Year

\begin{tabular}{|c|c|c|}
\hline & \multicolumn{2}{|c|}{ CY2011 } \\
\hline & \multicolumn{2}{|c|}{$N=32,044$} \\
\hline & $\mathrm{M} / f$ & $\mathrm{SD} / \%$ \\
\hline \multicolumn{3}{|l|}{ Demographics/characteristics } \\
\hline Female & 24,142 & $75.30 \%$ \\
\hline Age & 52.8 & 12 \\
\hline \multicolumn{3}{|l|}{ Geographic region } \\
\hline Mid-American & 13,550 & $42.30 \%$ \\
\hline Northeast & 2677 & $8.40 \%$ \\
\hline Southeast & 10,742 & $33.50 \%$ \\
\hline West & 5070 & $15.80 \%$ \\
\hline \multicolumn{3}{|l|}{ Benefit plan business type } \\
\hline Commercial & 32,033 & $99.90 \%$ \\
\hline Medicaid/Medicaid & 11 & $0.10 \%$ \\
\hline Charlson comorbidity index & 0.67 & 1.18 \\
\hline \multicolumn{3}{|l|}{ Specific comorbidities } \\
\hline Chronic pulmonary disease & 4885 & $15.20 \%$ \\
\hline Mild liver disease & 1516 & $4.70 \%$ \\
\hline Diabetes without complications & 3578 & $11.20 \%$ \\
\hline Depression & 3618 & $11.30 \%$ \\
\hline Osteoarthritis & 18,570 & $58.00 \%$ \\
\hline Chronic pain & 2293 & $7.20 \%$ \\
\hline Osteoporosis & 4002 & $12.50 \%$ \\
\hline Hypothyroidism & 5605 & $17.50 \%$ \\
\hline Disorders of lipid metabolism & 11,754 & $36.70 \%$ \\
\hline Hypertension & 12,539 & $39.10 \%$ \\
\hline
\end{tabular}

Note: Yearly samples are comprised of patients $>18$ years old meeting the definition of rheumatoid arthritis sometime during the measurement year.

$\mathrm{CY}=$ calendar year; $\mathrm{SD}=$ standard deviation. 


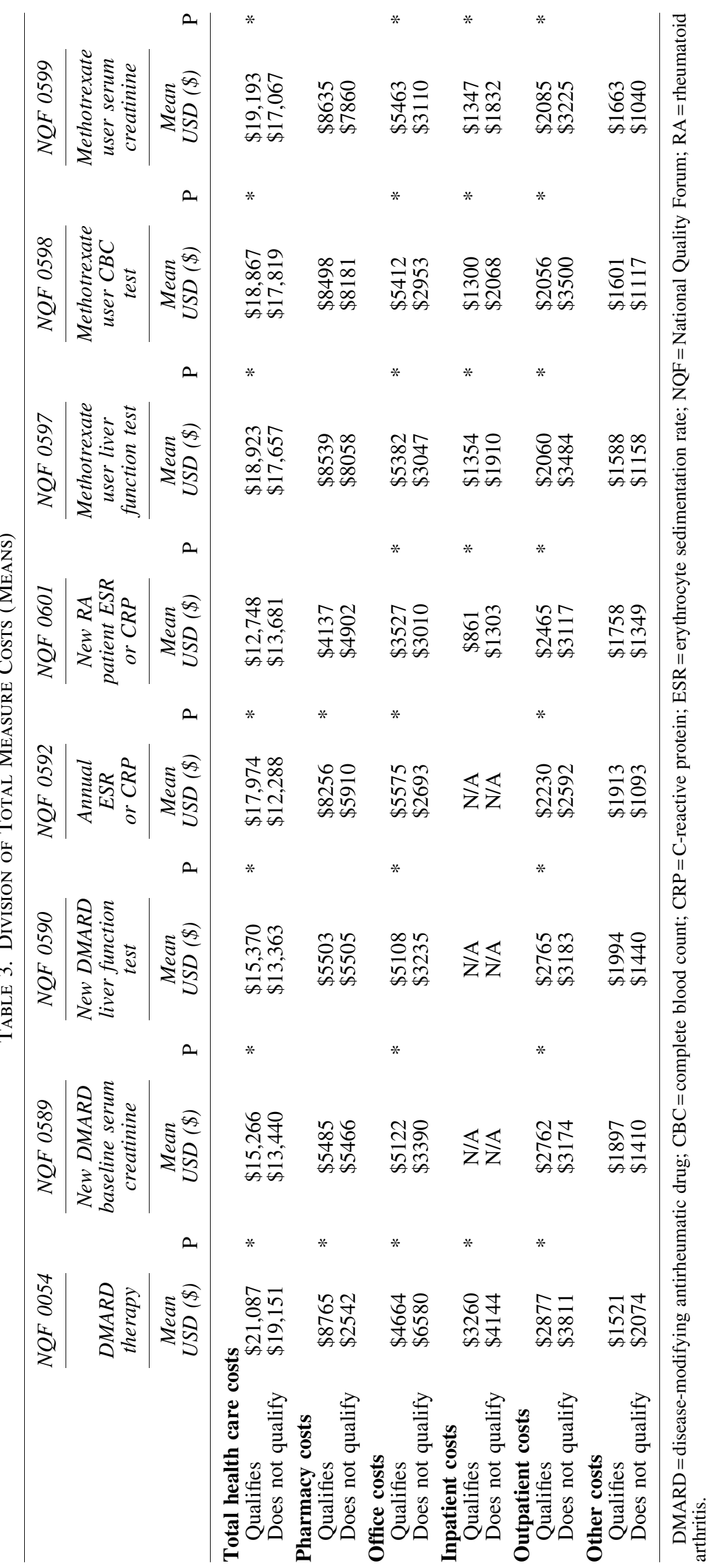




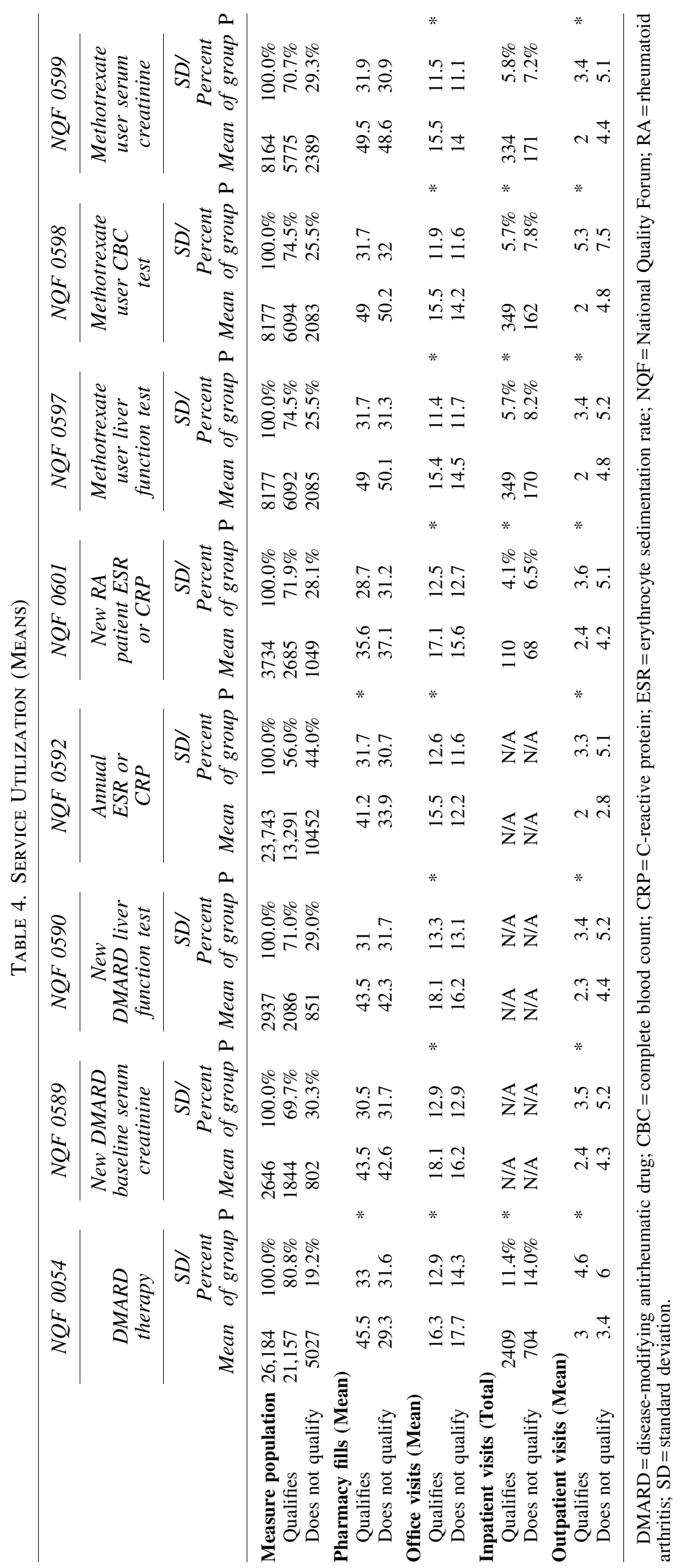


Table 5. Overall Rheumatoid Arthritis Costs AND SERVICE UtilizATION

\begin{tabular}{|c|c|c|c|}
\hline & $\begin{array}{c}\text { All } \\
\text { measures }\end{array}$ & $\begin{array}{l}\text { Qualifying } \\
\text { group }\end{array}$ & $\begin{array}{c}\text { Not qualifying } \\
\text { group }\end{array}$ \\
\hline Measure population & 83,762 & 59,024 & 24,738 \\
\hline \multicolumn{4}{|c|}{ Specific health care cost percentages } \\
\hline $\begin{array}{l}\text { Pharmacy } \\
\% \text { of total } \\
\% \text { of group }\end{array}$ & $42.4 \%$ & $\begin{array}{l}32.7 \% \\
43.8 \%\end{array}$ & $\begin{array}{r}9.6 \% \\
38.2 \%\end{array}$ \\
\hline $\begin{array}{l}\text { Office } \\
\% \text { of total } \\
\% \text { of group }\end{array}$ & $26.3 \%$ & $\begin{array}{l}20.2 \% \\
27.0 \%\end{array}$ & $\begin{array}{r}6.1 \% \\
24.0 \%\end{array}$ \\
\hline $\begin{array}{l}\text { Inpatient } \\
\% \text { of total } \\
\% \text { of group }\end{array}$ & $8.8 \%$ & $\begin{array}{l}6.5 \% \\
8.6 \%\end{array}$ & $\begin{array}{l}2.4 \% \\
9.4 \%\end{array}$ \\
\hline $\begin{array}{l}\text { Outpatient } \\
\% \text { of total } \\
\% \text { of group }\end{array}$ & $15.0 \%$ & $\begin{array}{r}9.8 \% \\
13.1 \%\end{array}$ & $\begin{array}{r}5.2 \% \\
20.7 \%\end{array}$ \\
\hline $\begin{array}{l}\text { Other } \\
\% \text { of total } \\
\% \text { of group }\end{array}$ & $7.5 \%$ & $\begin{array}{l}5.6 \% \\
7.5 \%\end{array}$ & $\begin{array}{l}1.9 \% \\
7.7 \%\end{array}$ \\
\hline \multicolumn{4}{|c|}{ Specific health care utilization means } \\
\hline $\begin{array}{l}\text { Pharmacy fills } \\
\text { Per person total } \\
\text { Per person group }\end{array}$ & 42.9 & $\begin{array}{l}31.8 \\
45.1\end{array}$ & $\begin{array}{l}11.2 \\
37.8\end{array}$ \\
\hline $\begin{array}{l}\text { Office visits } \\
\text { Per person total } \\
\text { Per person group }\end{array}$ & 15.5 & $\begin{array}{l}11.3 \\
16.0\end{array}$ & $\begin{array}{r}4.2 \\
14.3\end{array}$ \\
\hline $\begin{array}{l}\text { Outpatient visits } \\
\text { Per person total } \\
\text { Per person group }\end{array}$ & 2.7 & $\begin{array}{l}1.7 \\
2.4\end{array}$ & $\begin{array}{l}1.1 \\
3.6\end{array}$ \\
\hline
\end{tabular}

Members who attained measure 0054 (receiving a DMARD) and measure 0592 (annual erythrocyte sedimentation rate [ESR] or C-reactive protein [CRP] testing) incurred significantly higher pharmacy costs and filled a greater number of prescriptions than members who did not meet these measures $(P \mathrm{~s}<0.05)$. Office costs and visits significantly differed between groups and accounted for $26.3 \%$ of total costs. Members in the qualifying groups incurred significantly greater office costs than those in the non-qualifying groups on 7 of the 8 measures $(P \mathrm{~s}<0.05)$. Outpatient costs and visits also significantly differed between groups and comprised $15 \%$ of total costs. However, in contrast to office costs, patients in the non-qualifying groups incurred significantly greater outpatient costs than those in the qualifying groups $(P \mathrm{~s}<0.05)$. For the 5 measures in which inpatient costs were applicable, there were statistically significant differences between groups on all measures, with the non-qualifying groups incurring significantly greater inpatient costs $(P \mathrm{~s}<0.05)$. Inpatient costs accounted for $8.8 \%$ of total health care costs. Finally, there were statistically significant group differences in annual total health care costs on 7 of the 8 measures, with the qualifying groups incurring greater overall costs $(P \mathrm{~s}<0.05)$.

Given the disparity in biologic usage between qualifying and non-qualifying groups, for each measure, total health care costs were regressed onto measure qualifying disposition while controlling for biologic usage. Biologic utilization had a statistically significant relationship to total health care expenditure in all models $(P \mathrm{~s}<0.001)$. Pairwise comparisons of estimated marginal means controlling for biologic usage resulted in 5 statistically significant group differences (measures $0054,0592,0601,0597$, and 0598), with the qualifying groups demonstrating decreased costs compared to nonqualifying groups on 4 of these 5 measures (0592 the exception).

\section{Discussion}

The impact of increased quality in RA on overall health care costs remains unknown. As increased RA severity is associated with a 2.5 -fold increase in the cost of care, ${ }^{14}$ long-term cost savings may be associated with increased quality in care. These savings are more likely to be realized if quality is established early in treatment, promoting the prevention of disease progression and improved patient outcomes. The present study used administrative claims to examine the relationship between 8 RA process measures and health care cost and service utilization. Measure numerators and denominators in this data set were calculated and reported previously. ${ }^{19}$ As inclusion requirements for each numerator and denominator are independent for each measure, there is no common group of patients who meet the measures. Therefore, analyses were conducted for each measure individually (Tables 2 and 3), and total costs and service utilization rates for all measure groups were summed across all measures to obtain the proportion of total costs contributed by each group (Table 5). One caveat to this latter approach is that the same individual may be included in the numerator for one measure and the denominator for another.

Across all measures, measure achievement was associated with a trend toward increased service utilization and health care costs. For all measures with the exception of 0601, ESR or CRP testing in a new RA patient, members meeting the measure had a statistically higher annual per member cost, though differences between the groups who met and did not meet the measure only ranged between $\$ 2000$ and $\$ 5000$. There remains notable variation among the drivers of cost for members who do and do not meet the measures. The proportion of members who meet the measures had an increased percentage of health care costs attributed to pharmacy and office costs compared to members who did not meet the measures. The reverse is true for inpatient and outpatient costs, as well as the other cost category.

Across all 8 quality metrics, measure achievement groups statistically differed on office and outpatient visits, with the achievement groups exhibiting greater office visits and costs, and the non-achievement group exhibiting increased outpatient services and costs. Although pharmacy costs were similar on the whole, a statistical difference was present for measures 0054 and 0592; the increased use of biologic DMARDs by patients in the measure achievement groups likely accounted for the increased costs observed. These findings indicate that although patients who meet the measure have higher overall costs related to the intensive maintenance therapy and follow-ups necessary for RA treatment, they may have better controlled RA and require fewer expensive, and potentially preventable, inpatient or outpatient procedures. The increased use of biologic 
DMARDs in the population who meets the measure also may indicate that this group has had RA for a longer duration or more severe disease, as biologics are usually employed once other DMARDs fail. Differences in disease severity between the groups could account for the increased costs incurred by the measure achievement group. Reduced inpatient and outpatient costs observed for this potentially more severe group may point to a return on investment related to increased disease management.

The relatively similar total health care costs found between achievement groups is not completely unexpected. The overall goal of RA care is to reduce inflammation and prevent further joint damage, thereby inhibiting disease progression and enhancing patient quality of life. ${ }^{18}$ Treatment for RA is intensive and focuses on the use of maintenance medication to keep inflammation at a minimum ${ }^{11}$ and prevent disease flares, tissue damage, and overall disease progression, hopefully leaving patients with a better quality of life. $^{23,24}$ The requirement for maintenance medication in the treatment of RA, along with its widespread use (80.8\% of patients meet measure 0054, use of a DMARD), means that pharmacy costs for this disease will always account for a significantly higher portion of overall health care spending. Results of the regression analyses in this study found highly significant relationships between biologic use and overall health care expenditure $(P \mathrm{~s}<0.001)$. This increased cost is consistent with the amplification in pharmacy costs observed since the advent of biologics. ${ }^{10,12,14}$ Aside from the cost of the medication itself, use of DMARDs to treat RA requires extensive patient monitoring, resulting in increased use of services. The finding of slightly increased pharmacy costs and significantly increased office visits reported here is consistent with this maintenance medication approach for the treatment of RA.

This elevated use of pharmaceuticals in the treatment of RA, and the subsequent monitoring required, is reflected in the topics of the process measures. Of the 8 measures calculated for this study, 5 deal with monitoring for medication side effects (measures 0589, 0590, 0597, 0598, and 0599), 2 are in reference to monitoring for inflammation (measure 0592 and 0601), and 1 assesses DMARD use (measure 0054). These measures largely emanate from the Arthritis Foundation's 2004 quality indicator set, ${ }^{25}$ which was the first set of measures to be released. The NQF measures echo a portion of the Arthritis Foundation measures in their focus on pharmaceuticals, while other quality measure sets place emphasis on monitoring and assessment of patient disease activity and prognosis. Therefore, assessment of the NQF measures, although mostly unendorsed, provides a different perspective on RA quality care than can be assessed through other measure sets. Further, just as the Arthritis Foundation's 27-measure set has been collapsed by other quality reporting groups, it remains possible that quality metrics will shift again to include pharmaceutical measures, such as those calculated for this study.

There were a number of limitations in the current study. Despite the fact that administrative claims data are a rich source of data for analyses of health care service utilization and expenditure, they contain a few known inadequacies. For one, claims do not readily allow for assessment of patient clinical status. Proxies for disease severity, such as increased inpatient hospitalizations or outpatient services, can be assessed, yet these metrics remain estimations at best. The finding that inpatient and outpatient costs made up an increased proportion of total group costs for patients who did not meet the measures may suggest that patients who do not meet the measures have more severe or less well-controlled RA. Although this hypothesis cannot be definitively tested without greater insight into patients' clinical data, it is supported by reports that patients with the most severe disease incur, notably, 2.5-fold higher costs compared to patients with the least severe disease. ${ }^{10}$ Further, regarding claims, administrative coding errors and inconsistent use of billing codes likely exist. $^{26}$ One final limitation was the sample, which consisted solely of commercially insured health plan members, and it is unknown how results may generalize to members of Medicare or Medicaid, or to the uninsured.

The process measurement set examined in the present study was originally designed for use by physicians to assist in treatment and evaluation of their patients. The measures assess quality through completion of recommended tests or adherence with treatment pathways, but they do not address quality through direct patient outcomes. Analyses revealed that measure achievement ranged from $55.9 \%$ to $80.8 \%$. Across all measures, achievement was associated with an overall trend toward increased service utilization and health care costs for RA patients, but the increased service use was not evenly distributed across sites of care. Specifically, measure achievement was associated with greater office and pharmacy costs, while not achieving a measure(s) was associated with increased outpatient costs and, where applicable, inpatient costs. The finding here of decreased use of high-cost venue services within the group of patients meeting the quality measure is in line with findings in other chronic diseases. $^{5,27,28}$ The concurrent increase in office visits observed for the portion of patients meeting the measures may be indicative of patients receiving an increased level of oversight or being more compliant with their treatment regimens, consistent with an improved quality of overall care. .,28 $^{2}$

RA patients meeting the measures also exhibited elevated pharmacy costs compared to those individuals not meeting the measures. Adherence to pharmacological treatment regimens is associated with increased pharmacy costs related to use of medications. ${ }^{5}$ Yet, for chronic conditions such as cardiovascular disease and diabetes, adherence also is associated with increased positive patient outcomes and reduced morbidity. ${ }^{27,29-33}$ The cost savings associated with medication adherence emanate from the interplay between pharmacy and medical costs, as adherent patients have been shown to have more positive outcomes and reduced use of high-cost venue services, such as hospitalization, compared to nonadherent patients. $5,27,33$ For many diseases (eg, chronic heart failure, hypertension, diabetes, dyslipidemia), the increased pharmacy expenses incurred by adherent patients are offset by decreased medical expenses, particularly reduced use of inpatient and emergency services. ${ }^{5}$ Yet, there are other chronic conditions (eg, depression, asthma, osteoporosis) for which the increased pharmacy costs are not offset by reduced medical costs. ${ }^{5,31}$ In a disease such as RA, where the pharmacological regimen makes up a large proportion of overall costs and expensive brand name medications (eg, biologics) are a mainstay of treatment, the offset of pharmacy costs on total health care expenses is unlikely to be realized within a single calendar year. 
Additional studies that assess the association of quality health care and costs over an extended period are needed to further understand the impact of quality care and treatment regimens on a chronic disease such as RA. This particular set of process measures was only endorsed from December 4, 2009, to July 21, 2014; therefore, longitudinal analyses examining the relationship between costs and quality have yet to be realized. Extended longitudinal analyses using a claims-based approach are warranted to further quality improvement of health care and gain understanding of the associated cost of care for RA and other chronic diseases. Despite the known limitations of claims, these data are more accessible to both payers and quality groups than patient chart data, and the necessary longitudinal monitoring could be made possible through regular data refreshes. Such an approach may provide the analyses necessary to better quantify the long-term relationship between RA quality and health care expenditures.

\section{Author Disclosure Statement}

The authors declared the following potential conflicts of interest with respect to the research, authorship, and/or publication of this article: Drs. Meyer and Bolge are employees of Janssen Scientific Affairs, LLC, and own stock in Johnson \& Johnson. Drs. Brady and Ruetsch and Mr. Tkacz are employees of Health Analytics, which received research support from Janssen Scientific Affairs, LLC, to conduct this study.

The authors received the following financial support: Janssen Scientific Affairs, LLC, funded this study.

\section{References}

1. Anderson G, Horvath J. The growing burden of chronic disease in America. Public Health Rep 2004;119:263-270.

2. Grigor C, Capell H, Stirling A, et al. Effect of a treatment strategy of tight control for rheumatoid arthritis (the TICORA study): A single-blind randomised controlled trial. Lancet 2004;364(9430):263-269.

3. Holman H, Lorig K. Patients as partners in managing chronic disease: Partnership is a prerequisite for effective and efficient health care. BMJ 2000;320(7234):526-527.

4. Lorig KR, Mazonson PD, Holman HR. Evidence suggesting that health education for self-management in patients with chronic arthritis has sustained health benefits while reducing health care costs. Arthritis Rheum 1993;36:439446.

5. Roebuck MC, Liberman JN, Gemmill-Toyama M, Brennan TA. Medication adherence leads to lower health care use and costs despite increased drug spending. Health Aff (Millwood) 2011;30:91-99.

6. Scott DL, Wolfe F, Huizinga TW. Rheumatoid arthritis. Lancet 2010;376(9746):1094-1108.

7. Prevoo ML, van Gestel AM, van T Hoff MA, van Rijswijk $\mathrm{MH}$, van de Putte LB, van Riel PL. Remission in a prospective study of patients with rheumatoid arthritis: American Rheumatism Association preliminary remission criteria in relation to the disease activity score. $\mathrm{Br} \mathrm{J}$ Rheumatol 1996;35:1101-1105.

8. Cardarelli WJ. Implications for managed care and specialty pharmacy in rheumatoid arthritis. Am J Manag Care 2012; 18(Suppl 13):S315-S324.
9. Bansback N, Marra CA, Finckh A, Anis A. The economics of treatment in early rheumatoid arthritis. Best Pract Res Clin Rheumatol 2009;23(1):83-92.

10. Cooper NJ. Economic burden of rheumatoid arthritis: A systematic review. Rheumatology (Oxford) 2000;39(1): 28-33.

11. Singh JA, Furst DE, Bharat A, et al. 2012 update of the 2008 American College of Rheumatology recommendations for the use of disease-modifying antirheumatic drugs and biologic agents in the treatment of rheumatoid arthritis. Arthritis Care Res (Hoboken) 2012;64:625-639.

12. Michaud K, Messer J, Choi HK, Wolfe F. Direct medical costs and their predictors in patients with rheumatoid arthritis: A three-year study of 7,527 patients. Arthritis Rheum 2003;48:2750-2762.

13. van der Velde G, Pham B, Machado M, et al. Costeffectiveness of biologic response modifiers compared to disease-modifying antirheumatic drugs for rheumatoid arthritis: A systematic review Arthritis Care Res (Hoboken) 2011;63:65-78.

14. Yelin E, Wanke LA. An assessment of the annual and longterm direct costs of rheumatoid arthritis: The impact of poor function and functional decline. Arthritis Rheum 1999; 42:1209-1218.

15. Lard LR, Visser H, Speyer I, et al. Early versus delayed treatment in patients with recent-onset rheumatoid arthritis: Comparison of two cohorts who received different treatment strategies. Am J Med 2001;111:446-451.

16. Nell VP, Machold KP, Eberl G, Stamm TA, Uffmann M, Smolen JS. Benefit of very early referral and very early therapy with disease-modifying anti-rheumatic drugs in patients with early rheumatoid arthritis. Rheumatology (Oxford) 2004;43:906-914.

17. Pasma A, van't Spijker A, Hazes JM, Busschbach JJ, Luime JJ. Factors associated with adherence to pharmaceutical treatment for rheumatoid arthritis patients: A systematic review. Semin Arthritis Rheum 2013;43(1):18-28.

18. Smolen JS, Landewe R, Breedveld FC, et al. EULAR recommendations for the management of rheumatoid arthritis with synthetic and biological disease-modifying antirheumatic drugs. Ann Rheum Dis 2010;69:964-975.

19. Tkacz J, Ellis LA, Meyer R, Bolge SC, Brady BL, Ruetsch C. Quality process measures for rheumatoid arthritis: Performance from members enrolled in a national health plan. J Manag Care Spec Pharm 2015;21:135-143.

20. Hussey PS, Wertheimer S, Mehrotra A. The association between health care quality and cost: A systematic review. Ann Intern Med 2013;158:27-34.

21. National Quality Forum. Guiding quality care. 2013. Available at: <http://www.qualityforum.org/Home.aspx>. Accessed October 29, 2013.

22. Charlson ME, Pompei P, Ales KL, MacKenzie CR. A new method of classifying prognostic comorbidity in longitudinal studies: Development and validation. J Chronic Dis 1987;40:373-383.

23. Gaujoux-Viala C, Nam J, Ramiro S, et al. Efficacy of conventional synthetic disease-modifying antirheumatic drugs, glucocorticoids and tofacitinib: A systematic literature review informing the 2013 update of the EULAR recommendations for management of rheumatoid arthritis. Ann Rheum Dis 2014;73:510-515.

24. Nam JL, Ramiro S, Gaujoux-Viala C, et al. Efficacy of biological disease-modifying antirheumatic drugs: A systematic literature review informing the 2013 update of the 
EULAR recommendations for the management of rheumatoid arthritis. Ann Rheum Dis 2014;73:516-528.

25. MacLean $\mathrm{CH}$, Saag KG, Solomon DH, Morton SC, Sampsel S, Klippel JH. Measuring quality in arthritis care: Methods for developing the Arthritis Foundation's quality indicator set. Arthritis Rheum 2004;51:193-202.

26. Tyree PT, Lind BK, Lafferty WE. Challenges of using medical insurance claims data for utilization analysis. Am J Med Qual 2006;21:269-275.

27. Peterson ED, Roe MT, Mulgund J, et al. Association between hospital process performance and outcomes among patients with acute coronary syndromes. JAMA 2006;295: 1912-1920.

28. Sidorov J, Shull R, Tomcavage J, Girolami S, Lawton N, Harris R. Does diabetes disease management save money and improve outcomes? A report of simultaneous short-term savings and quality improvement associated with a health maintenance organization-sponsored disease management program among patients fulfilling health employer data and information set criteria. Diabetes Care 2002;25:684-689.

29. Fonarow GC, Gawlinski A, Moughrabi S, Tillisch JH. Improved treatment of coronary heart disease by implementation of a Cardiac Hospitalization Atherosclerosis Management Program (CHAMP). Am J Cardiol 2001;87:819-822.
30. Ho PM, Bryson CL, Rumsfeld JS. Medication adherence: its importance in cardiovascular outcomes. Circulation. 2009;119:3028-3035.

31. Ho PM, Rumsfeld JS, Masoudi FA, et al. Effect of medication nonadherence on hospitalization and mortality among patients with diabetes mellitus. Arch Intern Med 2006;166:1836-1841.

32. Marciniak TA, Ellerbeck EF, Radford MJ, et al. Improving the quality of care for Medicare patients with acute myocardial infarction: Results from the Cooperative Cardiovascular Project. JAMA 1998;279:1351-1357.

33. Sokol MC, McGuigan KA, Verbrugge RR, Epstein RS. Impact of medication adherence on hospitalization risk and healthcare cost. Med Care 2005;43:521-530.

Address correspondence to: Brenna L. Brady, PhD Health Analytics, LLC 9200 Rumsey Road, Suite 215 Columbia, MD 21045

E-mail: Bbrady@healthanalytic.com 